\title{
Quantitative Serum HBV DNA Levels During Different Stages of Chronic Hepatitis B Infection
}

\author{
Chi-Jen Chu, Munira Hussain, and Anna S. F. Lok
}

\begin{abstract}
The goals of this retrospective study were to determine whether there is a threshold hepatitis $B$ virus (HBV) DNA value associated with spontaneous or antiviral therapy-related hepatitis $B$ e antigen (HBeAg) clearance. We also investigated whether there is an HBV DNA value that can be used for differentiating inactive carriers from patients with $\mathrm{HBeAg-negative}$ chronic hepatitis B. HBV DNA levels in sequential serum samples of 165 Chinese patients with different stages of chronic $\mathrm{HBV}$ infection were quantified by a polymerase chain reaction (PCR)-based assay. Our results showed that almost all of the patients $(89 \%)$ who remained HBeAg-positive had HBV DNA levels that were persistently above $10^{5}$ copies $/ \mathrm{mL}$. Serum HBV DNA levels decreased by a mean of $3 \log _{10}$ in patients with $\mathrm{HBeAg}$ loss, but $51 \%$ had levels above $10^{5}$ copies/ $\mathrm{mL}$ at the time $\mathrm{HBeAg}$ first became undetectable. Mean serum HBV DNA levels were significantly lower in HBeAg-negative patients. HBV DNA value above $10^{5}$ copies $/ \mathrm{mL}$ would exclude all inactive carriers, but $45 \%$ of patients with $\mathrm{HBeAg}$ negative chronic hepatitis would also be excluded if testing were only performed at presentation and 30\% would be excluded if testing were performed on 3 occasions. In conclusion, serum HBV DNA levels decreased significantly in patients with HBeAg loss, but there was no threshold HBV DNA level associated with HBeAg clearance. Given the fluctuating course of HBeAg-negative chronic hepatitis, it is not possible to define a single cutoff HBV DNA value for differentiating inactive carriers from patients with HBeAg-negative chronic hepatitis. (HEPATOLOGY 2002;36:1408-1415.)
\end{abstract}

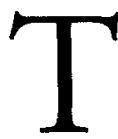
he evaluation of patients with hepatitis $B$ virus (HBV) infection has evolved from serologic to molecular diagnostic assays. Using polymerase chain reaction (PCR) assays, the vast majority of patients with chronic $\mathrm{HBV}$ infection, including those who are hepatitis $\mathrm{B}$ e antigen ( $\mathrm{HBeAg}$ ) negative and hepatitis $\mathrm{B} e$ antibody (anti-HBe) positive have detectable HBV DNA in serum. ${ }^{1-7}$ The improvement in sensitivity of $\mathrm{HBV}$

Abbreviations: $H B V$, hepatitis $B$ virus; $P C R$, polymerase chain reaction; $H B e A g$, hepatitis $B$ e antigen; anti-HBe, hepatitis $B$ e antibody; $A L T$, alanine aminotransferase; $H B s A g$, hepatitis $B$ surface antigen; IFN, interferon.

From the Department of Medicine, Division of Gastroenterology, University of Michigan Medical Center, Ann Arbor, MI.

Received June 24, 2002; accepted September 11, 2002.

Supported in part by the Liver Research Fund (A.S.F.L.). Roche provided the Cobas Amplicor HBV Monitor kits for quantitative HBV DNA assays. Innogenetics provided Inno-Lipa kits for $H B V$ genotyping and detection of precore stop codon and core promotor variants. C.J.C. was funded by a research fellowship from Taipei Veterans General Hospital and Research Foundation of Digestive Medicine, Republic of China. A.S.F.L. is supported by grants from NIDDK, NIH: NO1-DK-92323, 1UO1-DK-57577, and 1UO1-DK-60344.

Address reprint requests to: Anna S. F. Lok, M.D., Division of Gastroenterology, University of Michigan Medical Center, 3912 Taubman Center, Box 0362, Ann Arbor, MI 48109. E-mail: aslok@umich.edu; fax: 734-936-7392.

Copyright $(02002$ by the American Association for the Study of Liver Diseases. $0270-9139 / 02 / 3606-0016 \$ 35.00 / 0$

doi:10.1053/jhep.2002.36949
DNA assays has improved our understanding of the pathogenesis and natural history of HBV infection and facilitated the monitoring of response to treatment, but it also has generated new questions and dilemmas. ${ }^{8}$

Previous studies based on a single time point found that serum HBV DNA levels generally exceed $10^{5}$ copies/mL among patients with $\mathrm{HBeAg}$-positive chronic hepatitis and may be as high as $10^{10}$ copies $/ \mathrm{mL} \cdot{ }^{1-7}$ Serum HBV DNA levels tended to be lower $\left(10^{4}\right.$ to $10^{8}$ copies/ $\mathrm{mL}$ ) among patients with $\mathrm{HBeAg-negative} \mathrm{chronic} \mathrm{hepa-}$ titis B (HBeAg-negative, anti-HBe-positive, elevated alanine aminotransferase $[\mathrm{ALT}])^{3,4}$ and may be intermittently undetectable in non-PCR based assays. ${ }^{9,10}$ Until now, there have been very little data on what level of serum HBV DNA is associated with progressive liver disease. Consequently, there is no consensus on the level of serum HBV DNA when treatment is indicated.

A key question in the management of patients with HBeAg-positive chronic hepatitis B is to what level should serum HBV DNA be reduced to achieve sustained HBeAg seroconversion? To date, only 1 study had addressed this issue. In a study of 23 patients who received lamivudine therapy, $6(50 \%)$ of 12 patients whose serum HBV DNA decreased to $<10^{4}$ copies $/ \mathrm{mL}$ developed 
$\mathrm{HBeAg}$ seroconversion, versus none of 11 whose serum HBV DNA remained $>10^{4}$ copies $/ \mathrm{mL}$. ${ }^{11}$ This study suggested that there may be a threshold HBV DNA level associated with lamivudine-induced $\mathrm{HBeAg}$ seroconversion. However, this study was based on a very small number of patients. Thus, further studies are needed to validate this finding and to determine whether this threshold level applies to HBeAg seroconversion that occurs spontaneously or in association with other treatment.

An arbitrary serum HBV DNA level of $10^{5}$ copies $/ \mathrm{mL}$ has been proposed at the National Institutes of Health Workshop to differentiate chronic hepatitis B from an inactive carrier state ( $\mathrm{HBeAg-negative,} \mathrm{persistently} \mathrm{nor-}$ mal ALT). ${ }^{12}$ A recent study in France found that $98 \%$ of the inactive carriers had HBV DNA levels $<10^{5}$ copies $/ \mathrm{mL}$ at presentation and $97 \%$ had an HBV DNA level persistently below $10^{5}$ copies $/ \mathrm{mL}$ during a 1 - to 6 -year follow-up period. ${ }^{13}$ The investigators concluded that their results support the National Institutes of Health recommendation of $10^{5}$ copies $/ \mathrm{mL}$ as a cutoff HBV DNA value for differentiating inactive carriers from patients with chronic hepatitis $B$, but this study did not include patients with $\mathrm{HBeAg}$-negative chronic hepatitis B for comparison. Another study in Greece found that a cutoff value of $10^{5}$ copies $/ \mathrm{mL}$ would lead to misclassification of $13 \%$ of their patients with $\mathrm{HBeAg-negative} \mathrm{chronic} \mathrm{hep-}$ atitis $B$ and possibly denial of treatment. They suggested that a cutoff HBV DNA level of $3 \times 10^{4}$ copies $/ \mathrm{mL}$ is more appropriate for differentiating inactive carriers from patients with $\mathrm{HBeAg}$-negative chronic hepatitis B. ${ }^{14}$ However, HBV DNA was tested at 1 time point only in this study. Thus, the appropriate HBV DNA value for differentiating inactive carriers from patients with $\mathrm{HBeAg}$-negative chronic hepatitis $\mathrm{B}$ remains to be determined.
We performed this retrospective study to measure quantitative HBV DNA levels in sequential serum samples of patients with different stages of chronic HBV infection. Our goals were to determine (1) whether there is a threshold HBV DNA value associated with spontaneous or antiviral therapy-related $\mathrm{HBeAg}$ seroconversion, and (2) the HBV DNA value that should be used for differentiating inactive carriers from patients with $\mathrm{HBeAg}$-negative chronic hepatitis $B$.

\section{Patients and Methods \\ Patients}

This was a retrospective study using stored sera from Chinese patients with chronic HBV infection seen in the Hepatitis Clinic, Queen Mary Hospital, Hong Kong, between 1984 and 1992. Patients were seen every 3 to 6 months, or more often if clinically indicated. At each visit, liver biochemistry and $\mathrm{HBV}$ serology, including hepatitis B surface antigen ( $\mathrm{HBsAg}$ ), $\mathrm{HBeAg}$, and anti-HBe, were checked. Serum was collected and stored frozen at $-20^{\circ} \mathrm{C}$ for HBV DNA testing. All patients who had had at least 3 serum samples 1 year apart were studied. A total of 165 patients were included. These patients were classified into 5 groups: (1) persistently HBeAg-positive; (2) transient $\mathrm{HBeAg}$ loss/seroconversion: spontaneous (A) or interferon (IFN)-related (B); (3) sustained $\mathrm{HBeAg}$ loss/seroconversion: spontaneous (A) or IFN-related (B); (4) HBeAg-negative with persistent or intermittent elevation in ALT level; and (5) $\mathrm{HBeAg}$-negative with persistently normal ALT (Table 1). Except for patients in groups 2B and $3 \mathrm{~B}$, none of the patients received antiviral therapy during the study period.

\section{Definition}

The upper limit of normal for serum ALT was 45 IU/L. HBeAg loss was defined as disappearance of serum

Table 1. Timing of Blood Samples in the 5 Groups of Patients Studied

\begin{tabular}{|c|c|c|c|c|c|}
\hline Group & $\begin{array}{c}\text { Number of } \\
\text { Patjents }\end{array}$ & $\begin{array}{c}\text { Interval } \\
\text { Between 1st and } \\
\text { 2nd Samples } \\
\text { (mo) }\end{array}$ & 2nd Sample & $\begin{array}{c}\text { Interval } \\
\text { Between 2nd } \\
\text { and 3rd Samples } \\
\text { (mo) }\end{array}$ & 3rd Sample \\
\hline 1. Persistently HBeAg-positive & 27 & $21 \pm 2$ & Midway during FU & $22 \pm 2$ & Last FU \\
\hline \multicolumn{6}{|l|}{ 2. Transient HBeAg loss, spontaneous or } \\
\hline IFN-related & $27^{*}$ & $25 \pm 3$ & First HBeAg-negative & $8 \pm 3$ & Reappearance of $\mathrm{HBeAg}$ \\
\hline 3A. Sustained HBeAg loss, spontaneous & $25+$ & $31 \pm 3$ & First HBeAg-negative & $31 \pm 3$ & Last FU \\
\hline 3B. Sustained HBeAg loss, IFN-related & $24 \ddagger$ & $20 \pm 3$ & First HBeAg-negative & $40 \pm 4$ & Last FU \\
\hline \multicolumn{6}{|l|}{ 4. HBeAg-negative with persistent or } \\
\hline intermittently abnormal ALT & 33 & $28 \pm 2$ & Midway during FU & $26 \pm 2$ & Last FU \\
\hline 5. HBeAg-negative with persistently normal ALT & 29 & $28 \pm 2$ & Midway during FU & $34 \pm 2$ & Last FU \\
\hline
\end{tabular}

Abbreviations: HBeAg, hepatitis B e antigen; FU, follow-up; IFN, interferon; ALT, alanine aminotransferase.

*Fourteen spontaneous, 13 IFN-related, 13 developed anti-HBe.

†Eighteen developed anti-HBe.

$\ddagger$ Nineteen developed anti-HBe. 
HBeAg in a patient who previously had been HBeAgpositive. $\mathrm{HBeAg}$ seroconversion was defined as disappearance of $\mathrm{HBeAg}$ accompanied by the development of anti$\mathrm{HBe}$. Sustained $\mathrm{HBeAg}$ loss/seroconversion was defined as maintenance of this phenomenon for at least 1 year and until the last visit, with $\mathrm{HBeAg} / \mathrm{anti}-\mathrm{HBe}$ retested at least twice per year. $\mathrm{HBeAg}$ loss/seroconversion that occurred within 1 year after stopping IFN therapy was defined as IFN-related. Sustained biochemical remission was defined as persistently normal serum ALT from 6 months after first $\mathrm{HBeAg}$ loss until the last visit.

\section{Hepatitis B Serology}

The hepatitis B serologic markers $\mathrm{HBsAg}, \mathrm{HBeAg}$, and anti-HBe were tested using commercially available enzyme-linked immunosorbent assay kits from Abbott Laboratories (North Chicago, IL).

\section{Quantification of Serum HBV DNA Levels}

Serum HBV DNA levels were quantified using the Cobas Amplicor HBV Monitor kits according to the manufacturer's instructions (Roche Molecular Systems, Inc., Branchburg, NJ).4,7,15-17 The lower limit of detection of this assay is 200 copies $/ \mathrm{mL}$ (approximately 0.001 $\mathrm{pg} / \mathrm{mL}$ ) with a range of linearity up to $10^{6}$ copies $/ \mathrm{mL}$. Samples from patients who were $\mathrm{HBeAg-positive} \mathrm{were}$ initially tested after a 1 in 100,000 dilution; samples with undetectable HBV DNA were retested without dilution. Samples from patients who were $\mathrm{HBeAg}$-negative were initially tested undiluted; samples with HBV DNA results $\geq 10^{6}$ copies $/ \mathrm{mL}$ were retested after 1 in 100,000 dilution. An arbitrary value of 100 copies $/ \mathrm{mL}$ was assigned to samples with undetectable HBV DNA for statistical comparisons.

\section{HBV Genotyping}

The first available sample from each patient was used for HBV genotyping using a line-probe assay (Inno-Lipa $\mathrm{HBV}$ genotyping assay; Innogenetics, Inc., Ghent, Belgium). ${ }^{18-20}$ All necessary precautions to prevent crosscontamination were observed, and negative controls were included at each step. To validate the results of line probe assay, $10 \%$ randomly selected samples of genotypes $B$ and $\mathrm{C}$ and all samples with genotype $\mathrm{A}$ or $\mathrm{D}$ were sent for bidirectional automated sequencing at the DNA sequencing core facility, University of Michigan Medical Center, using the standard protocol for the Applied Biosystems DNA sequencer 377 (Perkin Elmer Corp., Foster City, CA). Sequencing results were compared with published sequences to ascertain HBV genotypes. ${ }^{21,22} \mathrm{HBV}$ genorype could be determined by line-probe assay in all patients who had detectable HBV DNA by PCR. Com- parison between results of direct sequencing and the lineprobe assay showed $100 \%$ concordance.

\section{Precore Stop Codon Variant $\left(G_{1896} A\right)$ and Core Promotor Variant $\left(A_{1762} T, G_{1764} A\right)$}

Serial samples from patients with sustained $\mathrm{HBeAg}$ seroconversion (group 3) and initial samples of HBeAgnegative patients (groups 4 and 5) were tested for precore (PC) stop codon $\left(\mathrm{G}_{1896} \mathrm{~A}\right)$ and core promotor (CP) $\left(\mathrm{A}_{1762} \mathrm{~T}, \mathrm{G}_{1764} \mathrm{~A}\right)$ variants using Inno-Lipa precore/core promotor kits (Innogenetics, Inc.). 19,20 Except for the primers, the procedure was similar to that for HBV genotyping. All samples with indeterminate results and $20 \%$ of randomly selected samples with $\mathrm{PC}$ and/or $\mathrm{CP}$ variant were sent for direct sequencing as described above. Indeterminate results were obtained in only $2 \%$ of samples in the $\mathrm{PC}$ and $9 \%$ in the $\mathrm{CP}$ region using the line-probe assay. Of the samples that could be typed, the concordance between the line-probe assay and sequencing was $99 \%$. The line-probe assay was more sensitive in detecting mixed sequences than direct sequencing.

\section{Statistical Analyses}

Results were expressed as mean \pm standard error. Data were entered into an Excel database and analyzed using SPSS version 9.0 software package (SPSS, Inc., Chicago, IL). Statistical analyses were performed using $\chi^{2}$ and Fisher's exact test for categorical variables. Paired or unpaired Student's $t$ test or one-way ANOVA with Tukey test was used for continuous variables as appropriate. Results were considered statistically significant at $P<.05$.

\section{Results}

The demographics, baseline liver histology, results of HBV genotyping, and serial quantitative HBV DNA and ALT values are summarized in Tables 2 and 3 .

\section{Group 1: Persistently HBeAg-Positive, $n=27$}

Serum HBV DNA levels varied from $10^{5-10}$ copies $/ \mathrm{mL}$ with a slight $\left(<1 \log _{10}\right)$ decline during a mean follow-up of $43 \pm 3$ months (range, 24 to 88 months) (Fig. 1A). There was no correlation between serum HBV DNA and ALT levels. HBV DNA levels above $10^{5}$ copies $/ \mathrm{mL}$ were observed in $96 \%$ of the samples. None of the patients in this group had HBV DNA levels persistently below $10^{5}$ copies/mL.

\section{Group 2: Transient HBeAg Loss/Seroconversion: Spontaneous or IFN-Related, $n=27$}

Serum HBV DNA levels decreased by a mean of 3 $\log _{10}$ to $10^{3-8}$ copies $/ \mathrm{mL}$ when $\mathrm{HBeAg}$ first became undetectable and increased by a mean of $2 \log _{10}$ with the reap- 
Table 2. Demographics, Baseline Histology, and HBV Genotypes of Patients Studied

\begin{tabular}{lccccc}
\hline Group & $\begin{array}{c}\text { Gender } \\
\text { (M/F) }\end{array}$ & $\begin{array}{c}\text { Mean Age } \\
(\mathbf{y r})\end{array}$ & $\begin{array}{c}\text { Number (\%) of Patients } \\
\text { With Liver Biopsies }\end{array}$ & $\begin{array}{c}\text { Histology } \\
\text { (NS/CH/cirrhosis) }\end{array}$ & $\begin{array}{c}\text { HBV Genotypes } \\
\text { (A/B/C/D) }\end{array}$ \\
\hline 1 & $20 / 7$ & $24 \pm 1$ & $13(48)$ & $5 / 6 / 2$ & $0 / 8 / 19 / 0$ \\
2 & $22 / 5$ & $32 \pm 2$ & $21(78)$ & $2 / 13 / 6$ & $0 / 5 / 21 / 1$ \\
$3 A$ & $12 / 13$ & $29 \pm 2$ & $14(56)$ & $8 / 4 / 2$ & $0 / 12 / 13 / 0$ \\
$3 B$ & $17 / 7$ & $29 \pm 1$ & $23(96)$ & $6 / 14 / 3$ & $0 / 11 / 12 / 1$ \\
4 & $24 / 9$ & $34 \pm 2$ & $6(18)$ & $0 / 5 / 1$ & $0 / 12 / 19 / 0$ \\
5 & $9 / 20$ & $0(0)$ & $0 / 0 / 0$ & $1 / 11 / 7 / 1$ \\
\hline
\end{tabular}

Abbreviations: HBV, hepatitis B virus; NS, nonspecific changes; $\mathrm{CH}$, chronic hepatitis.

pearance of $\mathrm{HBeAg}$ (Fig. 1B). There was no difference in absolute value or degree of decline of the HBV DNA level between patients with spontaneous or IFN-related transient $\mathrm{HBeAg}$ loss.

\section{Group 3: Sustained HBeAg Loss/Seroconversion: Spontaneous (A), $n=25$, or IFN-Related (B), $n=24$}

HBV DNA Level and HBeAg Loss. Thirty-seven $(76 \%)$ of these 49 patients developed anti-HBe, simultaneous with the loss of $\mathrm{HBeAg}$ in 26 patients and after a mean of $10 \pm 3$ months (range, 1 to 30 months) after $\mathrm{HBeAg}$ first became undetectable in the remaining 11 patients. Serum HBV DNA levels decreased by a mean of $3 \log _{10}$ to $10^{3-7}$ copies/mL when $\mathrm{HBeAg}$ first became undetectable (Fig. 1C). HBV DNA levels above $10^{6}, 10^{5}$, and $10^{4}$ copies $/ \mathrm{mL}$ were found in $38 \%, 51 \%$, and $63 \%$ patients, respectively, at the time when $\mathrm{HBeAg}$ first became undetectable. After $\mathrm{HBeAg}$ loss, a further decline in serum HBV DNA levels by 1 to $1.5 \log _{10}$ was observed during a mean follow-up of $35 \pm 3$ months (range, 12 to 81 months).

Baseline HBV DNA levels were similar among the 3 groups of patients ( 1 to 3 ) who were $\mathrm{HBeAg}$-positive at presentation (mean, 7.9 to $8.3 \log _{10}$ copies $/ \mathrm{mL}$ ). HBV DNA levels at the time when HBeAg first became undetectable were comparable in groups 2 and 3 patients, mean levels being $4.98 \pm 0.21$ and $4.99 \pm 0.24 \log _{10}$ copies $/ \mathrm{mL}$, respectively. Within each of the 2 groups of patients with $\mathrm{HBeAg}$ loss (2 and 3), HBV DNA levels at the time when $\mathrm{HBeAg}$ first became undetectable were similar in patients with spontaneous versus IFN-related $\mathrm{HBeAg}$ loss, and in patients with or without anti-HBe seroconversion (Table 4).

HBV DNA Level and Sustained Biochemical Remission. Thirty-eight (78\%) patients had sustained biochemical remission after $\mathrm{HBeAg}$ loss. Patients with sustained biochemical remission had a lower HBV DNA level at the time of $\mathrm{HBeAg}$ loss (mean, $4.80 \pm 0.26 \mathrm{vs}$. $5.67 \pm 0.53 \log _{10}$ copies $/ \mathrm{mL}$ ) and at the last follow-up visit (mean, $3.74 \pm 0.18$ vs. $4.07 \pm 0.56 \log _{10}$ copies/ $\mathrm{mL}$ ), but these differences were not statistically significant. Figure 2 shows a patient who had sustained biochemical remission after $\mathrm{HBeAg}$ seroconversion, and Fig. 3 shows a patient with persistently elevated ALT after $\mathrm{HBeAg}$ seroconversion.

HBV DNA Level and Selection of Precore or Core Promotor Variants. Of the 49 patients with sustained HBeAg loss/seroconversion, 16 (33\%) had core promoter and $3(6 \%)$ had precore variant as the dominant sequence at presentation, whereas $17(35 \%)$ had core promotor and $16(33 \%)$ had precore variant as the dominant sequence when $\mathrm{HBeAg}$ first became undetectable. Serum HBV DNA levels at the time of $\mathrm{HBeAg}$ loss were comparable between patients with and without precore variants (Table 5) and in patients with and without core promotor variants $(4.87 \pm 0.41$ vs. $\left.5.40 \pm 0.32 \log _{10}\right)$. The prevalence of precore (13 of 38

Table 3. Serial HBV DNA and ALT Levels of Patients Studied

\begin{tabular}{|c|c|c|c|c|c|c|c|}
\hline \multirow[b]{2}{*}{ Group } & \multicolumn{3}{|c|}{ 1st Sample } & \multicolumn{2}{|c|}{ 2nd Sample } & \multicolumn{2}{|c|}{ 3rd Sample } \\
\hline & $\begin{array}{l}\text { Mean Log } 10 \text { HBV } \\
\text { DNA (Coples/mL) }\end{array}$ & $\begin{array}{c}\text { Number (\%) With } \\
\text { Undetectable } \\
\text { HBV DNA }\end{array}$ & $\begin{array}{c}\text { Mean ALT } \\
(I U / L)\end{array}$ & $\begin{array}{c}\text { Mean } \log _{10} \text { Change in } \\
\text { HBV DNA From 1st } \\
\text { Sample }\end{array}$ & $\begin{array}{c}\text { Mean ALT } \\
(I U / L)\end{array}$ & $\begin{array}{c}\text { Mean } \log _{10} \text { Change } \\
\text { in HBV DNA From } \\
\text { 2nd Sample }\end{array}$ & $\begin{array}{l}\text { Mean } \\
\text { ALT } \\
\text { (IU/L) }\end{array}$ \\
\hline 1 & $8.37 \pm 0.22$ & $0(0)$ & $149 \pm 45$ & $-0.39 \pm 0.33$ & $69 \pm 19$ & $-0.28 \pm 0.28$ & $93 \pm 22$ \\
\hline 2 & $7.86 \pm 0.32$ & $0(0)$ & $210 \pm 49$ & $-2.87 \pm 0.35$ & $80 \pm 18$ & $1.59 \pm 0.37$ & $87 \pm 14$ \\
\hline $3 A$ & $8.31 \pm 0.28$ & $0(0)$ & $105 \pm 23$ & $-3.10 \pm 0.40$ & $71 \pm 19$ & $-1.44 \pm 0.32$ & $27 \pm 4$ \\
\hline $3 B$ & $7.74 \pm 0.35$ & $0(0)$ & $108 \pm 15$ & $-2.96 \pm 0.34$ & $69 \pm 19$ & $-0.91 \pm 0.40$ & $29 \pm 3$ \\
\hline 4 & $5.17 \pm 0.33$ & $2(6)$ & $118 \pm 23$ & $0.39 \pm 0.29$ & $190 \pm 35$ & $-0.81 \pm 0.33$ & $85 \pm 21$ \\
\hline 5 & $3.10 \pm 0.17$ & $9(31)$ & $18 \pm 2$ & $0.18 \pm 0.17$ & $17 \pm 1$ & $-0.16 \pm 0.13$ & $20 \pm 1$ \\
\hline
\end{tabular}

Abbreviations: HBV, hepatitis B virus; ALT, alanine aminotransferase. 
A

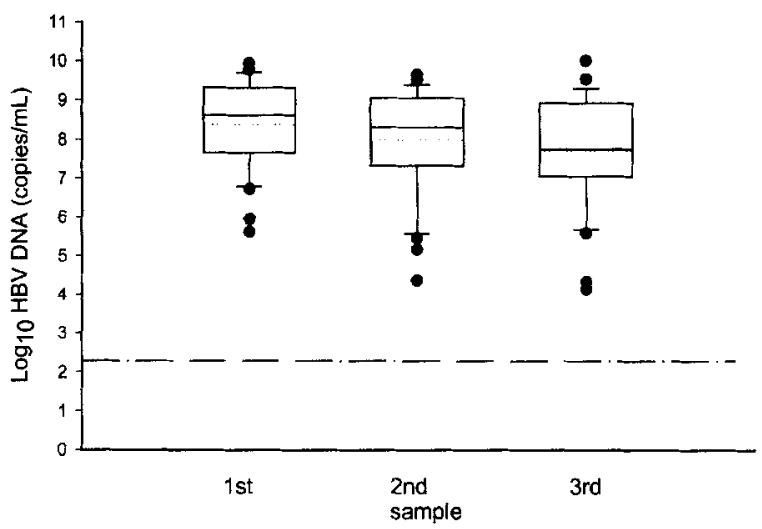

C

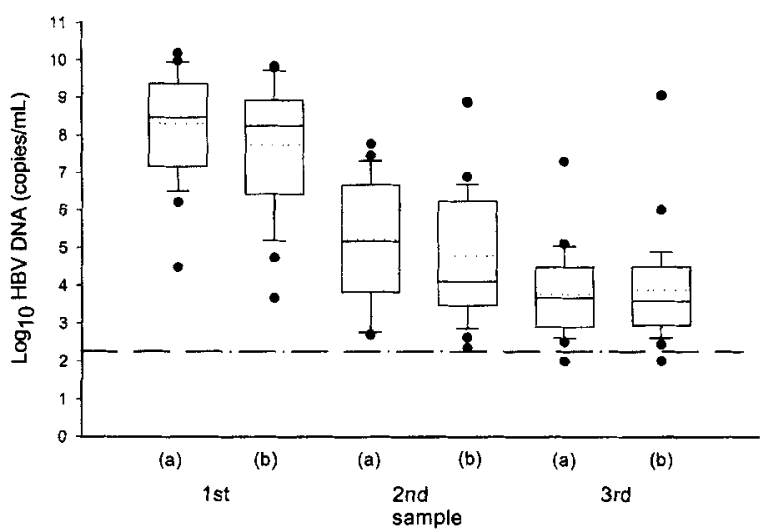

$\mathbf{E}$

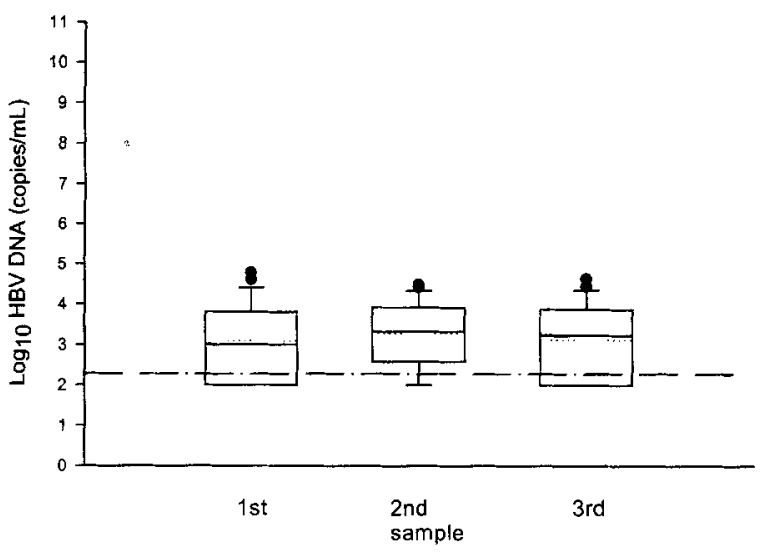

vs. 3 of 11) and core promotor (12 of 38 vs. 5 of 11) variants at the time when $\mathrm{HBeAg}$ first became undetectable was similar between patients with and without sustained biochemical remission.

\section{Group 4: HBeAg-Negative With Persistent or Intermittently Abnormal ALT, $n=33$}

Compared with patients who were $\mathrm{HBeAg}$-positive, this group of patients had significantly lower serum
B

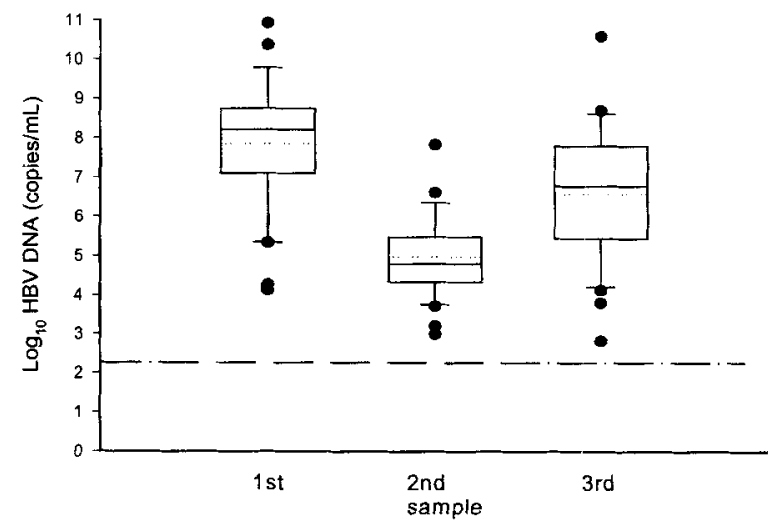

D

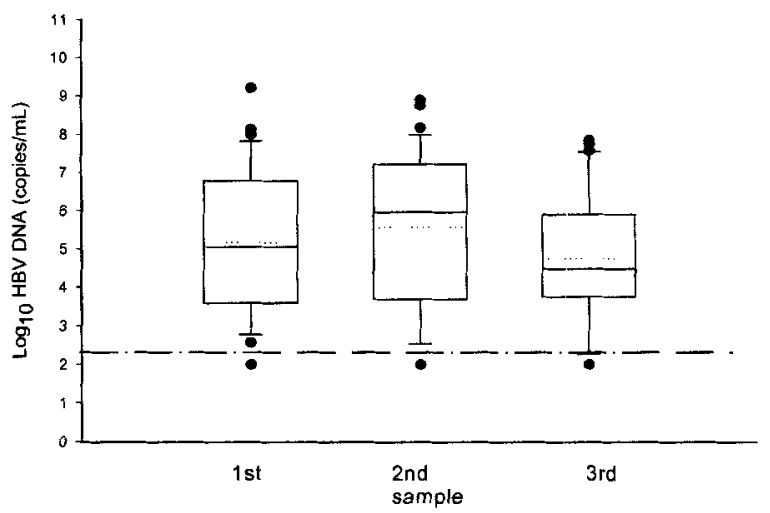

Fig. 1. $\log _{10}$ HBV DNA levels of patients during follow-up. (A) Group 1, HBeAg-positive patients; (B) group 2, HBeAg-positive patients with transient HBeAg loss; (C) group 3, HBeAg-positive patients with sustained HBeAg loss: (a) spontaneous and (b) IFN-related; (D) group 4, HBeAg-negative patients with persistent or intermittently abnormal ALT; and $(E)$ group 5, HBeAg-negative patients with persistently normal ALT. The box plots showed the 10th, 25th, 50th, 75th, and 90th percentiles and outliers (circles). Mean HBV DNA level is indicated as a dotted line within the box. The lower limit of detection ( 200 copies $/ \mathrm{mL}$ ) is expressed as a dash-dot line.

HBV DNA leveis; mean, $5.2 \log _{10}$ versus $8.4 \log _{10}$ copies $/ \mathrm{mL}(P<.001)$. There was a wide range in $\mathrm{HBV}$ DNA levels at presentation $\left(10^{3-8}\right.$ copies $/ \mathrm{mL}$ ) (Fig. 1D) and during the course of follow-up (Fig. 4). About half $(47 \%)$ of the samples had HBV DNA levels less than $10^{5}$ copies $/ \mathrm{mL}$. HBV DNA levels persistently greater than $10^{5}, 10^{4}$, and $10^{3}$ copies $/ \mathrm{mL}$ were found in $33 \%, 58 \%$, and $82 \%$ patients, respectively. Twenty- 
Table 4. Serial HBV DNA Levels in Group 3 Patients Who Lost HBeAg With and Without HBeAg Seroconversion

\begin{tabular}{lccc}
\hline & HBeAg Seroconversion & HBeAg Loss Only & P Value \\
\hline Number of patients & 37 & 12 & \\
Mean \pm SEM HBV DNA (log 10 copies/mL) & & & \\
At presentation & $8.12 \pm 0.23$ & $7.68 \pm 0.69$ & NS \\
At the time of HBeAg loss & $5.11 \pm 0.26$ & $4.55 \pm 0.55$ & NS \\
Last follow-up & $3.78 \pm 0.20$ & $3.92 \pm 0.46$ & NS \\
\hline
\end{tabular}

Abbreviations: HBV, hepatitis B virus; $\mathrm{HBeAg}$, hepatitis B e antigen; NS, not significant.

three $(70 \%)$ patients had at least 1 sample with an HBV DNA level $>10^{5}$ copies $/ \mathrm{mL}$.

Nine patients of this group had persistently abnormal ALT levels during the follow-up period. Patients with persistently abnormal ALT levels tend to have a higher HBV DNA level at presentation as compared with patients with intermittently abnormal ALT level $(6.11 \pm$ $0.76 \log _{10}$ copies $/ \mathrm{mL}$ vs. $4.82 \pm 0.34 \log _{10}$ copies $/ \mathrm{mL}, P$ $=.08)$. At presentation, the $\mathrm{CP}$ variant as the dominant sequence was found in $59 \%$ of patients and the $\mathrm{PC}$ variant was found as the dominant sequence in $36 \%$ of patients (Table 6). HBV DNA level was comparable between patients with and without the PC variant $(5.52 \pm 0.30$ vs. $5.30 \pm 0.48 \log _{10}$ copies $/ \mathrm{mL}$ ).

\section{Group 5: HBeAg-Negative With Persistently Normal $A L T, n=29$}

The HBV DNA level in this group was significantly lower than that of patients in group 4, the mean HBV DNA level at presentation being $3.1 \log _{10}$ copies $/ \mathrm{mL}(P$ $<.001$ ). At presentation, the $C P$ variant as the dominant sequence was found in $30 \%$ of patients and the $\mathrm{PC}$ variant as the dominant sequence was found in $50 \%$ of patients (Table 6). HBV DNA levels remained stable during a mean follow-up period of $62 \pm 3$ months (range, 41 to 92 months). Twenty-six (90\%) patients had detectable HBV

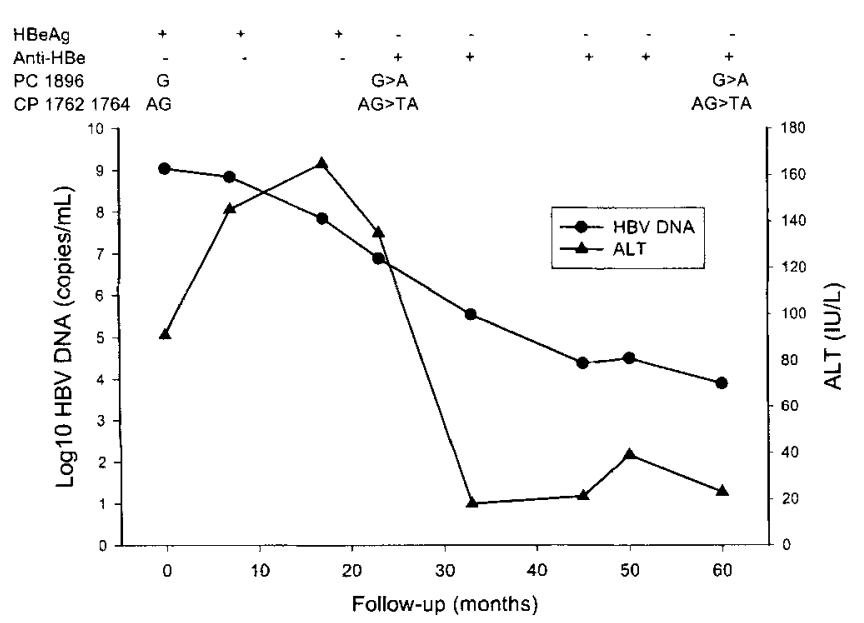

Fig. 2. HBV DNA and ALT levels in one patient with sustained biochemical remission after $\mathrm{HBeAg}$ seroconversion.
DNA in at least 1 of their 3 samples, and $15(52 \%)$ had persistently detectable serum HBV DNA. All of the samples had HBV DNA levels lower than $10^{5}$ copies $/ \mathrm{mL}$. Only $2(7 \%)$ patients had HBV DNA levels persistently higher than $10^{4}$ copies $/ \mathrm{mL}$.

\section{Discussion}

In accordance with previous reports, ${ }^{1-7}$ we found that more than $90 \%$ of $\mathrm{HBeAg}$-positive patients had serum HBV DNA levels that could be detected by non-PCR assays, which have detection limits of $10^{5-6}$ copies $/ \mathrm{mL}$. In this study, the correlation between HBV DNA and ALT levels in $\mathrm{HBeAg}$-positive patients was poor, possibly related to immune tolerance secondary to perinatal infection in many of our patients.

A previous small-scale study on lamivudine-treated patients suggested that HBV DNA levels must be reduced to less than $10^{4}$ copies $/ \mathrm{mL}$ for $\mathrm{HBeAg}$ seroconversion to occur. ${ }^{11}$ Our results showed a wide range in HBV DNA levels $\left(10^{3.7}\right.$ copies $\left./ \mathrm{mL}\right)$ at the time HBeAg first became undetectable, implying that there is no threshold $\mathrm{HBV}$ DNA level for $\mathrm{HBeAg}$ clearance/seroconversion. This observation was true for spontaneous as well as IFN-related $\mathrm{HBeAg}$ clearance/seroconversion. Because our samples were collected in the prelamivudine era, we cannot ascer-

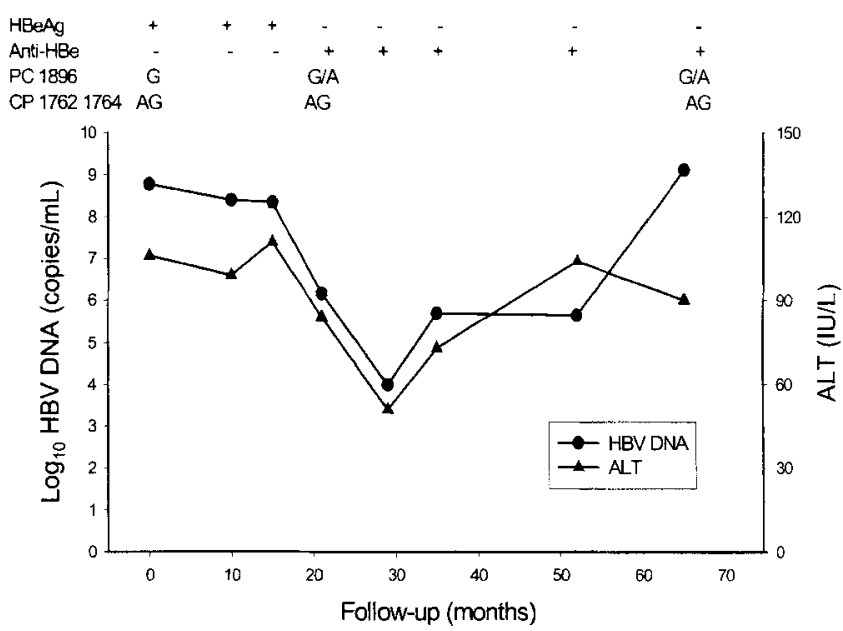

Fig. 3. HBV DNA and ALT levels in one patient without biochemical remission after HBeAg seroconversion. 
Table 5. Serial HBV DNA Levels in Group 3 Patients Who Lost HBeAg With and Without Selection of Precore $G_{1896} A$ Mutation

\begin{tabular}{lccc}
\hline & $\begin{array}{c}\text { With Selection } \\
\text { of PC Variant }\end{array}$ & $\begin{array}{c}\text { Without Selection } \\
\text { of PC Variant }\end{array}$ & P Value \\
\hline $\begin{array}{l}\text { Number of patients } \\
\text { Mean } \pm \text { SEM HBV DNA }\end{array}$ & 16 & 33 & \\
$\quad\left(\log _{10}\right.$ copies $\left./ \mathrm{mL}\right)$ & & & \\
Sample 1 & & & \\
Sample 2 & $8.41 \pm 0.29$ & $7.82 \pm 0.35$ & NS \\
Sample 3 & $5.62 \pm 0.32$ & $5.00 \pm 0.35$ & NS \\
\hline
\end{tabular}

Abbreviations: $\mathrm{HBV}$, hepatitis $\mathrm{B}$ virus; $\mathrm{HBeAg}$, hepatitis $\mathrm{B}$ e antigen; $\mathrm{PC}$, precore; NS, not significant.

tain whether our results can be generalized to nucleo$\mathrm{s}(\mathrm{t})$ ide therapy-related $\mathrm{HBeAg}$ clearance. All of our patients were ethnically Chinese, most of whom had perinatally acquired HBV infection. Thus, it is not clear whether our results can be generalized to patients with adult-acquired HBV infection.

Interestingly, we found no difference in HBV DNA levels at the time $\mathrm{HBeAg}$ first became undetectable between patients with transient and sustained $\mathrm{HBeAg}$ loss, indicating that serum HBV DNA level at this time point is not a good predictor of durability of HBeAg loss. In addition, our study showed that HBV DNA levels at the time of $H B e A g$ loss were similar in patients with and without anti-HBe seroconversion. In patients with sustained $\mathrm{HBeAg}$ loss, there was a further reduction in $\mathrm{HBV}$ DNA levels during follow-up. However, HBV DNA remained detectable by PCR in $96 \%$ of patients $35 \pm 3$ months after sustained $\mathrm{HBeAg}$ loss.

As in our previous reports, ${ }^{9,20,23}$ we found that patients with sustained $\mathrm{HBeAg}$ loss were more likely to be infected with $\mathrm{HBV}$ genotype $\mathrm{B}$, that $\mathrm{HBeAg}$ clearance can occur in the absence of detectable mutations that abolish or decrease $\mathrm{HBeAg}$ production, and that selection of precore or

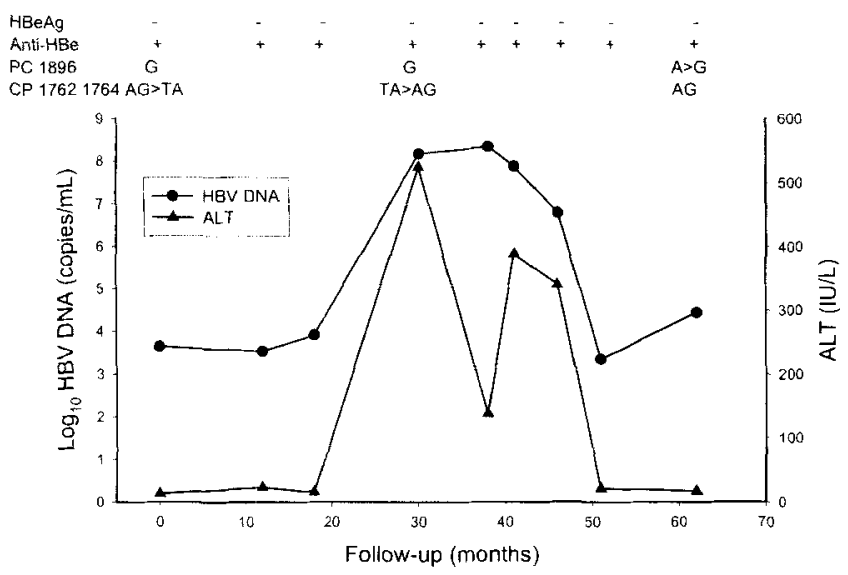

Fig. 4. HBV DNA and ALT levels in one patient with HBeAg-negative chronic hepatitis $B$.
Table 6. Core Promotor/Precore Sequence of Group 4 and 5 Patients at Presentation

\begin{tabular}{lcc}
\hline & Group 4 & Group 5 \\
\hline Number of patients & 33 & 29 \\
HBV DNA-positive by PCR & $31(94 \%)$ & $20(69 \%)$ \\
CP (1762, 1764) sequence & & \\
WT only & $6(19 \%)$ & $11(55 \%)$ \\
WT $>$ CP Var & $6(19 \%)$ & $1(5 \%)$ \\
CP Var $>$ WT & $2(7 \%)$ & $0(0 \%)$ \\
CP Var only & $16(52 \%)$ & $6(30 \%)$ \\
Other mutations* & $1(3 \%)$ & $2(10 \%)$ \\
PC (1896) sequence & & \\
WT only & $15(48 \%)$ & $7(35 \%)$ \\
WT > PC Var & $4(13 \%)$ & $2(10 \%)$ \\
PC Var > WT & $3(10 \%)$ & $4(20 \%)$ \\
PC Var only & $8(26 \%)$ & $6(30 \%)$ \\
Other point mutation & $1(3 \%)$ & $1(5 \%)$ \\
WT-dominant sequence in both CP and PC regions & $7(23 \%)$ & $6(30 \%)$ \\
\hline
\end{tabular}

Abbreviations: $C P$, core promotor; $P C$, precore; $H B V$, hepatitis $B$ virus; $P C R$, polymerase chain reaction; WT, wild type; $C P$ Var, $A_{1762} T G_{1764} A ; P C$ Var, $G_{1896} A$.

*Including single mutation $A_{1762} T$ and $G_{1764} A$, deletions, and other point mutations.

core promotor variants after $\mathrm{HBeAg}$ loss was not necessarily associated with a higher HBV DNA or ALT level. In accordance with recent literature, ${ }^{24}$ not all patients with sustained $\mathrm{HBeAg}$ seroconversion had sustained biochemical remission. Although $36 \%$ of the parients without sustained biochemical remission had a transient ALT flare, the remaining $64 \%$ had intermittent or persistently abnormal ALT values. The latter pattern explains why some patients develop progressive liver disease despite sustained $\mathrm{HBeAg}$ seroconversion.

The National Institutes of Health workshop on management of hepatitis $B$ proposed that a serum HBV DNA level of $10^{5}$ copies $/ \mathrm{mL}$ be used to differentiate chronic heparitis $B$ from an inactive carrier state. ${ }^{12}$ Our results showed that a HBV DNA value above $10^{5}$ copies $/ \mathrm{mL}$ would exclude all inactive carriers but also $45 \%$ of patients with $\mathrm{HBeAg-negative} \mathrm{chronic} \mathrm{hepatitis} \mathrm{if} \mathrm{testing}$ were only performed at presentation and 30\% if testing were performed on 3 occasions. Decreasing the cutoff value to $3 \times 10^{4}$ copies $/ \mathrm{mL}$ would misclassify $7 \%$ of inactive carriers and $30 \%$ of patients with HBeAg-negative chronic hepatitis if testing were only performed at presentation. Given the variable course of HBeAg-negative chronic hepatitis $B$, retesting on more than one occasion helps in differentiating patients with $\mathrm{HBeAg}$ negative chronic hepatitis from inactive carriers, but no single $\mathrm{HBV}$ DNA value reliably differentiates these 2 groups. In accordance with other reports, ${ }^{13}$ we found that serum HBV DNA remained detectable in the vast majority of inactive carriers, but HBV DNA levels tend to be lower and to remain stable over a 5-year follow-up period. 
In summary, we found that serum HBV DNA levels were very high $\left(10^{5-10}\right.$ copies $\left./ \mathrm{mL}\right)$ in $\mathrm{HBeAg}$-positive patients. Serum HBV DNA levels decreased by a mean of 3 $\log _{10}$ in patients who had spontaneous or IFN-related HBeAg loss, but there was no threshold HBV DNA level associated with $\mathrm{HBeAg}$ clearance. Serum HBV DNA level at the time of $\mathrm{HBeAg}$ loss was not a predictor of durability of $\mathrm{HBeAg}$ loss. A further decline in serum $\mathrm{HBV}$ DNA levels was observed in patients with sustained $\mathrm{HBeAg}$ loss regardless of anti-HBe seroconversion. Serum HBV DNA levels were significantly lower in $\mathrm{HBeAg-neg-}$ ative patients, but levels as high as $10^{9}$ copies $/ \mathrm{mL}$ were detected. Although all of the inactive carriers had HBV DNA levels that were persistently below $10^{5}$ copies $/ \mathrm{mL}$, only $33 \%$ of patients with HBeAg-negative chronic hepatitis had HBV DNA levels that were persistently above $10^{5}$ copies $/ \mathrm{mL}$. Given the fluctuating course of $\mathrm{HBeAg}$ negative chronic hepatitis $B$, it is not possible to define a single cutoff HBV DNA value for differentiating inactive carriers from patients with $\mathrm{HBeAg-negative} \mathrm{chronic} \mathrm{hep-}$ atitis.

\section{References}

1. Loeb KR, Jerome KR, Goddard J, Huang ML, Cent A, Corey L. Highthroughput quantitative analysis of hepatitis $B$ virus DNA in serum using the TaqMan fluorogenic detection system. HePA'ToIOGY 2000;32:626629.

2. Noborg U, Gusdal A, Horal P, Lindh M. Levels of viraemia in subjects with serologic markers of past or chronic hepatitis B virus infection. Scand J Infect Dis 2000;32:249-252.

3. Niitsuma H, Ishii M, Miura M, Kobayashi K, Toyota T. Low level hepatitis $B$ viremia detected by polymerase chain reaction accompanies the absence of $\mathrm{HBe}$ antigenemia and hepatitis in hepatitis B virus carriers. Am J Gastroentefol 1997;92:119-123.

4. Gerken G, Gomes J, Lampertico P, Colombo M, Rothaar T, Trippler M, Colucci G. Clinical evaluation and applications of the Amplicor HBV Monitor $^{\text {TM }}$ test, a quantitative HBV DNA PCR assay. J Virol Methods 1998;74:155-165.

5. Fujiwara K, Yokosuka O, Ehata T, Chuang WL, Imazeki F, Saisho $H$, Omata $M$. The two different states of hepatitis $B$ virus DNA in asymptomatic carriers: $\mathrm{HBeAg-antigen-positive} \mathrm{versus} \mathrm{anti-HBe-positive}$ asymptomatic carriers. Dig Dis Sci 1998;43:368-376.

6. Lindh $M$, Horal P, Dhillon AP, Norkrans G. Hepatitis B virus DNA levels, precore mutations, genotypes and histological activity in chronic hepatitis B. J Viral Hepatitis 2000;7:258-267.

7. Kessler HH, Preininger S, Stelzl E, Daghofer E, Santner BI, Marth E, Lackner $\mathrm{H}$, et al. Identification of different states of hepatitis $\mathrm{B}$ virus infection with a quantitative PCR assay. Clin Diagn Lab Immun 2000;7: 298-300.
8. Chu CI, Lok AS. Clinical utility of quantifying serum HBV DNA levels using PCR assays. J Hepatol 2002;36:549-551.

9. Chan HLY, Leung NWY, Hussain M, Wong ML, Lok ASF. Hepatitis B e antigen-negative chronic hepatitis B in Hong Kong. HEPATOLOGY 2000; 31:763-768

10. Jardi R, Buti M, Rodriguez-Frias F, Cortina M, Esteban R, Guardia J, Pascual $C$. The value of quantitative detection of HBV-DNA amplified by PCR in the study of hepatitis B infection. J Hepatol 1996;24:680-685.

11. Gauthier J, Bourne EJ, Lutz MW, Crowther LM, Dienstag JL, Brown NA, Condreay LD. Quantitation of hepatitis $B$ viremia and emergence of YMDD variants in patients with chronic hepatitis B treated with lamivudine. J Infect Dis 1999;180:1757-1762.

12. Lok AS, Heathcore EJ, Hoofnagle JH. Management of Hepatitis B 2000, Summary of a Workshop. Gastroenterology 2001;120:1828-1853.

13. Martinot-Peignoux $M$, Boyer N, Colombat $M$, Akremii R, Pham BN, Castelnau C, Valla D, et al. Serum HBV DNA levels and liver histology in inactive HBsAg carriers. J Hepatol 2002:36:543-546.

14. Manesis EK, Papatheodoridis GV, Hadziyannis SJ. Serum HBV DNA levels in inactive hepatitis B virus carriers. Gastroenterology 2002;122: 2092-2093.

15. Ranki M, Schatzl HM, Zachoval R, Uusi-Oukari M, Lehtovaara P. Quantification of hepatitis $B$ virus DNA over a wide range from serum studying viral replicative activity in response to treatment and in recurrent infection. HEPATOLOGY 1995;21:1492-1499.

16. Noborg U, Gusdal A, Pisa EK, Hedrum A, Lindh M. Automated quantitative analysis of hepatitis $B$ virus DNA by using the Cobas Amplicor HBV Monitor test. J Clin Microbiol 1999;37:2793-2797.

17. Pawlorsky JM, Bastie A, Hezode C, Lonjon I, Darthuy F, Remire J, Dhumeaux D. Routine detection and quantification of hepatitis $B$ virus DNA in clinical laboratories: performance of three commercial assays. J Virol Methods 2000;85:11-21.

18. Teles SA, Martins RMB, Vanderborght B, Stuyver L, Gasper AMC, Yoshida CFT. Hepatitis B virus: genotypes and subtypes in Brazilian hemodialysis patients. Artif Organs 1999;23:1074-1078.

19. Grandjacques C, Pradat P, Stuyver L, Chevallier M, Chevallier P, Pichoud $C$, Maisonnas $M$, et al. Rapid detection of genotypes and mutations in the pre-core promotor and the pre-core region of hepatitis $\mathrm{B}$ virus genome: correlation with viral persistence and disease severity. J Hepatol 2000;33: 430-439.

20. Chu CJ, Hussain M, Lok ASF. Hepatitis B virus genorype B is associated with earlier $\mathrm{HBcAg}$ seroconversion compared to hepatitis $B$ virus genorype C. Gastroenterology 2002;122:1756-1762.

21. Norder H, Courouce AM, Magnius LO. Complete genomes, phylogenetic relatedness and structural proteins of six strains of the hepatitis B virus, four of which represent two new genotypes. Virology 1994;198:489-503.

22. Stuyver L, de Gendt S, van Geyt C, Zoulim F, Fried M, Schinazi RF, Rossau R. A new genotype of hepatitis B virus: complete genome and phylogenetic relatedness. J Gen Virol 2000;81:67-74.

23. Lok AS, Akarca U, Greene S. Mutation in the pre-core region of hepatitis $B$ virus serve to enhance the stability of the secondary structure of the pre-genome encapsidation signal. Proc Natl Acad Sci U S A 1994;91: $4077-4081$

24. Hadziyannis SJ, Vassilopoulos D. Hepatitis e antigen-negative chronic hepatitis B. HePATOLOGY 2001;34:617-624. 